\title{
Rural unions and the struggle for land in Brazil
}

\section{Clifford Andrew Welch \& Sérgio Sauer}

To cite this article: Clifford Andrew Welch \& Sérgio Sauer (2015) Rural unions and the struggle for land in Brazil, The Journal of Peasant Studies, 42:6, 1109-1135, DOI: 10.1080/03066150.2014.994511

To link to this article: https://doi.org/10.1080/03066150.2014.994511

\section{Published online: 22 May 2015.}

Submit your article to this journal 준

Llll Article views: 730

View Crossmark data ¿

Citing articles: 8 View citing articles ¿ 


\title{
Rural unions and the struggle for land in Brazil
}

\author{
Clifford Andrew Welch and Sérgio Sauer
}

\begin{abstract}
Studies of Brazil's agricultural labor movement have generally neglected its relationship to the struggle for land, but this is neither fair nor accurate. Analyzing the rural labor movement's historical contributions to the land struggle in Brazil, this contribution has been organized into three main periods, emphasizing social relations, institutional activism and policy changes. It argues that despite the peculiarities of different historical contexts, rural labor consistently provoked protest against policies that privileged large landholders, whose concentration of power over land and labor resources continually worsened Brazil's ranking as one of the most unequal of nations. For more than half a century, the most constant opponent of this situation among the peasantry has been the National Confederation of Workers in Agriculture (CONTAG), a corporatist organization of rural labor unions founded in 1963.
\end{abstract}

Keywords: rural labor organizations; peasants; agrarian reform; land struggle; family farmers; Brazil

\section{Introduction}

Studies of Brazil's agricultural labor movement have generally neglected its relationship to the struggle for land, but this is neither fair nor accurate (Price 1964; Medeiros 1989; Ricci 1999; Welch 1999; Martins 2002). Since its conception in the early twentieth century, the rural worker movement has been concerned with peasant reproduction, land access and usage. Since the rural union movement pre-dates the Landless Rural Workers Movement (MST, in its Brazilian acronym) and all other contemporary land struggle organizations in Brazil, the latter movements cannot be understood without considering the former. Despite a reluctance to adopt direct action tactics in the 1980s, when land occupations - one of the most ancient forms of land access - became the signature tactic of the MST, the largest rural labor movement, represented by the National Confederation of Workers in Agriculture (CONTAG, in its Brazilian acronym), supported a significant number of these actions from the second half of the 1990s (NERA 2013).

Despite the peculiarities of different historical periods, peasant rebellions consistently provoked protest against development models that privileged large landholders, whose concentration of power over land and labor resources continued to shape Brazil's trajectory (Linhares and Silva 1999; Carvalho 2004; Fernandes, Welch, and Gonçalves 2012). From colonial times to the late nineteenth century, sugarcane planters and sugar mill owners articulated their predominance of Brazil's northeastern region with a sizable subaltern population of small producers of food and providers of skilled labor. With the decline of African slavery, most of these peasants were forced to surrender their autonomy as the planters laid claim to their farms and their lives, recreating them as dependent resident 
workers who were only permitted to produce food for their own consumption (Palacios 2009). In nearly every corner of Brazil, peasants cleared forest and brush to create farmland, only to have it taken from them by the combined power of armed landlord henchmen and compliant government authorities. In fact, it is difficult to think of a situation in the countryside where labor issues were not directly connected to landholding, or where forms of peasant resistance did not shape the systems produced.

The beginning of sustained challenges to landlord hegemony can be dated from the anarchist, socialist and communist movements that became established in Brazil in the early twentieth century as a consequence of European immigration (Hall and Pinheiro 1985). The vast majority of immigrants came to work in agriculture, especially on coffee plantations in São Paulo state, whose plantation owners and government subsidized the voyages of thousands of mostly Italian, Spanish and Portuguese families beginning in the mid-1800s (Davatz 1980). The protests of these immigrants as well as fellow Brazilian workers, including some recently emancipated slaves of African descent, shaped a labor relations system known as the colonato. Important to this system was the ability to accumulate enough capital to buy one's own farm. The colonos, as coffee workers were called, sought to accomplish this by gaining permission from landlords to plant crops for their own sale or use in the furrows between rows of coffee trees. When these terms were not agreeable, conflicts occurred, some rising to the level of involving thousands of colonos, such as the coffee worker strikes of 1912 and 1913, which benefitted from the organizing efforts of anarchists and socialists. These disputes continued into the 1920s, when Brazilian radicals organized the Communist Party of Brazil (PCB, in its Brazilian acronym; Vangelista 1991; Welch 2010).

Writing for this journal in 2002, Brazilian sociologist José de Souza Martins toyed with the multiple meanings of representation when he titled his contribution 'Representing the peasantry', and yet discussed the organizations established to represent rural labor only in the last few pages. For most of the paper, Martins used the term to emphasize the variety of words other than 'peasantry' used to portray changes in the structural conditions of agriculture. These changes have depended upon varied forms of labor exploitation to extract value from the land, from enslaved to free resident workers compelled to pay rent through forced labor obligations, from dependent workers tapping rubber trees in the Amazon to immigrant families colonizing small farms in the south, from independent family farmers to today's debt-burdened contract farmers. He argued that 'the key to present agrarian struggles, and to the agrarian question itself, lies not so much in the system of landholding as in changes to the labor regime introduced by rural employers' (Martins 2002, 203). While the variety of land-labor relationships is a striking characteristic of the rural development process in a country as large and geographically diverse as Brazil (Bastos 1987), in contrast to Martins (2002), we argue that the key to present agrarian struggles lies in the organizations involved in 'representing the peasantry', including rural labor unions, this paper's main focus.

A starting point for our critique of Martins (2002) is his conclusion that 'peasantry' is not an appropriate term since its late use in Brazil is linked to political options of 'mediating agents' like the MST, and that the 'rural subject' is too complex to be 'amalgamated ... into a uniform "Brazilian peasantry" with a uniform political interest' (327). First, the Portuguese word for peasant, camponês, can be found in colonial documents, including court proceedings in which they sought to defend their interests (Palacios 2009). In one of Martins' older studies of the Brazilian countryside (1981), he alleged that the word first appeared in the 1950s when some peasant leagues (Ligas Camponesas) became well known. But the Communist Party had employed the term publicly in the 1920s. Second, 
the uniformity alleged by Martins does not appear to be the goal of any of the organizations we discuss. In contradistinction to Martins, we opt to use the term because of its openness and flexibility, a word intended to be all-inclusive of the complex relations between those who work on the land and socioeconomic structures, as temporary or permanent wage earners, squatters or propertied small family farmers, hunters or gatherers of forest products, or rural crafts-people. Third, our emphasis on representative organizations means that our rural labor subjects are in processes of consciousness-raising in regards to their rights. Since at least the 1920s, this politically aware rural worker has frequently called him or herself a peasant.

To present the rural labor movement's historical contributions to the land struggle in Brazil, we organized the paper into three main sections. Following chronological order, each emphasizes social relations and institutional activism in particular structural contexts. In the first part, the paper analyzes the post-World War II struggle for recognition on the part of the peasantry, a period when the emerging movements operated almost entirely outside the law. In close relation to communist influences, such struggles and social mobilizations resulted in the creation of both a farm labor law in 1963 and a land law in 1964. The second part of the contribution examines attempts by the newly legalized labor movement to implement and use the land law as part of rural labor's demands in the context of the military regime that took power in a coup d'etat in April 1964. This part concludes with a discussion of the unions' struggle to shape agrarian reform law in drafting Brazil's new federal constitution in 1988, some 3 years after the return to civilian government. In the final part, the essay analyzes union efforts to modify and fulfill the promises of these new constitutional rights. As lawfully empowered entities, the unions 'needed' to work within established legal frameworks, but the strategies and tactics developed to achieve their goals shifted, depending on a variety of factors, between tendencies of negotiation with/support for authorities and opposition to/demands against the state and landlords. Throughout, we chart the tension between these two poles and note how the labor movement sought institutional recognition in the 1950s and 1960s, both challenged and collaborated with the dictatorship and added to its tool kit with redemocratization direct-action tactics such as land occupations, and yet embraced neoliberal policies as part of its historic contribution to agrarian reform struggle in Brazil.

\section{Rural land and labor struggle for legal recognition to 1964}

The organization with the longest history of action among Brazilian peasants in the twentieth century is the Communist Party. ${ }^{1}$ In 1928 , this party initiated a popular front strategy by forming the Worker-Peasant Block to institutionalize joint political mobilization of peasants and proletarians in support of the so-called national bourgeoisie and their efforts to strengthen Brazil through the nationalization of control over resources and manufacturing. Most activity revolved around electoral politics, especially the 1930 presidential election. As part of the Soviet Union's Communist International, established in 1919 to overthrow the so-called international bourgeoisie, the Communist Party was prohibited from

\footnotetext{
${ }^{1}$ Founded in 1922, the PCB was called the Communist Party of Brazil until a breakaway organization chose the same name for itself in 1962. To retain its acronym, the PCB changed its name to the Brazilian Communist Party and the new party adopted the acronym PCdoB. During the dictatorship, both gave attention to peasant mobilization, with the PCB emphasizing unionization and the PCdoB stressing armed struggle until 1974, when nearly all guerrilla groups had been repressed.
} 
functioning openly, especially after 1930 when a rebellion brought to power a new government led by Getúlio Vargas. Nevertheless, in the 1930s, the Communist Party registered peasants as members and stimulated collective struggles in the countryside, an activity the Vargas government seemed to favor given its plans to build a corporatist state, with all economic categories organized into representative syndicates (Karepovs 2006; Welch 2009b).

Vargas made some efforts to control peasant mobilization through rural labor unionization, but the rural oligarchy resisted and ultimately blocked these plans until 1945, when a palace coup forced Vargas to leave the government (Welch 1999). The new political liberties of the post-World War II era permitted open competition by the Communist Party, which led the party to form Peasant Leagues in the countryside to defend rural labor interests and build its political base. Under liberalized voter-registration laws, the Communist leagues signed up hundreds if not thousands of new voters, who helped win the election of several Communist Party candidates to public office. Communist delegates who participated in the Constituent Assembly of 1946 influenced the content of Brazil's new federal constitution. Although many of their initiatives did not win majority support, for the next two decades constitutional articles that enabled the state to 'condition land use' to 'social welfare' standards, and specified goals of 'fixing men in the countryside' and 'justly distributing property', played important roles in determining peasant struggle (Brazil 1946; Welch 1999).

Even before May 1947, when the government canceled the Communist Party's mandate and forced members to act clandestinely, landlords and local police had repressed many leagues; others continued to function after the suppression of the Communist Party. The latest evidence of their existence can be found in police documents from 1949. In that year, the party founded a newspaper called Nossa Terra (Our Country/Land) to address the agrarian question and mobilize the peasantry to confront landlords. Until 1964, Communists used the publication under the name Terra Livre (Free Country/Land) to mobilize peasants with stories of struggles from all over the country, news of organizing efforts, legal orientation, popular poems and political journalism (Medeiros 1989; Welch 2010).

At various moments of its underground history, the Communist Party dedicated resources to defending the peasantry. In the early $1950 \mathrm{~s}$, it offered military training and material aid to a group of peasant families who had taken up arms to defend their possession of small coffee farms in the so-called 'Porecatu War' in the state of Paraná (Priori 2011). During the period, the party became involved in additional armed conflicts in Paraná and other southern states. In the center-west region of the country, the Communist Party also integrated itself with hundreds of peasants to defend their autonomy and influence over the micro-region of Trombas and Formoso, part of the Uruaçu municipality in the state of Goiás, where the Vargas government had experimented with an internal colonization scheme (Cunha 2007).

In September 1954, communist strategists recognized the importance of the Trombas and Formoso struggle by selecting one of its leaders, Geraldo Tibúrcio, as president of the newly formed Union of Farmers and Agricultural Workers of Brazil (ULTAB, in its Brazilian acronym). The party staged ULTAB's founding in São Paulo at a national congress of peasant delegates recruited from around the country. At the party's IV Congress in November 1954, Communist Party leaders expressed their admiration for Chinese revolutionaries and upheld the peasantry in Goiás as the nucleus of rural mobilization that would carry Brazil toward its own revolution (Welch 2010). Although ULTAB never succeeded in reproducing the Trombas and Formoso model of resistance on a broader scale, the peasants 
of Uruaçu were able to maintain a 'liberated region' until repressed by the military dictatorship after the 1964 coup (Cunha 2007).

Overall, the peasantry did not fare well in their confrontations with the state and large landowners, since troops and armed gunmen supported the rural oligarchy. In the Porecatu conflict, police troops and intelligence specialists from São Paulo helped defeat the resistance movement, and six peasants died. Various other conflicts exploded throughout the country, generally inspired by resistance to diverse forms of exploitation and, especially, forced expulsion from the land. As a result of these losses, the Communist Party central committee eventually concluded that revolution in Brazil would be a prolonged process, similar to the Chinese experience but with little chance of forming a popular army in the countryside. Thus, ULTAB militants followed a course of action dedicated to pressuring the state to comply with existing land and labor laws, among them the 'social welfare' test of landholding, minimum wages, paid holidays and advanced notice of contract termination. Especially important was the Communist Party's utilization of a presidential decree, passed by Vargas in 1945, which permitted the 'organization of rural life' through formal registry of small farmer 'associations' in each municipality (Welch 2010).

The Communist Party's advances in the countryside occurred in the context of an unprecedented period of electoral democracy and mass mobilization, much of it justified by an economic development discourse that called on popular participation to modernize the country. By demonstrating the ability of peasants to mobilize, the party stimulated other political actors to campaign in favor of incorporating peasants into the rural modernization project (Welch 2006a). Among these other actors were the Brazilian Labor Party, the Christian Democratic Party and the Brazilian Socialist Party (Camargo 1986). The Catholic Church also stepped up its participation. Perpetually present at the level of parishes, the church generally worked to buttress the established order, offering biblical apologies to justify rural poverty and the suffering peasants. However, increased communication and democratic politics provoked new voices and approaches, with one wing continuing to call on peasants to be patient and tolerate their exploitation in order to guarantee their place in heaven, while another wing began to practice a more activist ministry by helping the peasants understand their human and civil rights and organize to claim them (Sauer 1996).

Those more sensitive to the worldly needs of the peasantry initially attempted to form associations to join landowners and peasants in one united organization, insisting they would enhance harmony between classes rather than conflict. Certain bishops promoted these initiatives to retain peasant congregations by uniting with planters in secular associations that interpreted private property as a 'natural right', seeking to overcome the suffering of peasants through the subsidized purchase of parcels no longer useful to landlords (Welch 1999). In August 1955, they hosted the Congress for the Salvation of the Northeast in Recife, capital of Pernambuco state. Emphasizing social harmony, politicians from various states, representing various political parties, and delegates from newly formed rural associations issued resolutions calling for massive federal intervention to promote the development of the region. Such strategies would soon be criticized as 'drought industry' theater, taking advantage of peasant participation to reinforce the control of dominant groups (Almeida 1991). A segment of this same wing eventually spoke out against joint associations, supporting the need for peasants to form their own organizations (Welch 1999).

In analyzing the countryside in the mid-1950s, another group based in the northeast must be discussed. Influenced by the Pernambucan lawyer and socialist politician Francisco Julião, various peasant groups throughout the northeastern states began organizing 
themselves. These peasants were predominantly resident sugar cane plantation workers, subordinated by landlord prerogatives in exchange for limited land-use rights for animal husbandry and gardening (Montenegro 2004; Palacios 2009). In order to protect basic interests, such as schools for their children and the burial costs of elders, they organized themselves into mutual aid societies. The established order soon saw these associations as a threat and referred to them as peasant leagues in an attempt to link them to the old Communist Party groups and thus social disorder (Julião 2009). Julião had worked for years advocating for the civil rights of peasants using Brazil's 1906 Civil Code, which recognized 'tenure' as a key test for legitimating land rights. In January 1955, Julião legally registered the first mutual aid society - a group of 140 peasants living on the abandoned Galiléia sugar mill. The movement and Julião's political career took off in 1959 when the state government expropriated the mill and distributed its land to the peasant families who resided there (Welch 2010).

In 1961, the Communist Party central committee advised ULTAB officers to organize a peasant congress. This call came at a moment of national and international political crisis, which delayed its organization. The Cuban Revolution of 1959 marked a Cold War flare-up in the Americas, causing the United States to support a project of military and socio-economic intervention in the region called the Alliance for Progress. In August, in the Uruguayan city of Punta del Este, Brazil joined 21 other Latin American nations in signing the alliance agreement with the United States. The agreement directed each Latin American signatory to develop agrarian reform policies and plans. A few days later, Brazilian President Janio Quadros suddenly resigned, provoking a serious constitutional crisis, made all the more dramatic with Vice President João Goulart on an official visit in China. In this Cold War climate, Goulart's enemies depicted him as a communist 'fellow traveler' - an image reinforced by his presence in Communist China - and dangerous to the security of the Americas due to his close relationship to the labor movement. Centrist and leftist groups generally supported him as an able conciliator of class conflict, and defended his legal right to fill the post abandoned by Quadros. The Communist Party mobilized millions of people, including peasants, defending the constitutional transition and helping to guarantee that Goulart assumed the presidency (Ferreira 2011, Welch 2010).

Right after this crisis, ULTAB resumed the campaign for a national peasant congress, calling for delegates to participate from its small-farmer associations, Julião's Peasant Leagues and the more progressive wing of the Catholic Church. In November 1961, the peasant congress met in Belo Horizonte, with hundreds of leaders from different groups and organizations, coming from all parts of Brazil. Congress organizers wanted to unite these different organizations under the clandestine tutelage of the Communist Party in order to illuminate common peasant problems and plan a coordinated response. However, the congress's political agenda was divided between those who emphasized the rights of farmworkers and those who defended land distribution as the main cause of the peasantry.

In relation to the land question, three distinct positions characterized debate in the congress, a debate often reflective of arguments among factions within each organization. For the predominant groups within ULTAB, agrarian reform offered a means to eliminate the archaic traces of feudalism in rural areas by breaking up large, unproductive estates that served as a source of power for antidemocratic and antinationalist forces, such as traditional elites and foreign corporations. For Catholics and government representatives, agrarian reform promised to boost national economic development by lowering food costs and expanding the domestic market, thereby strengthening capitalism and the working class, as one step towards socialism. For most Peasant League delegates, agrarian reform 
advanced socialism by redistributing the means of production to those who worked the land, promoting social justice. While the first two groups sought to achieve change through legal means, Julião's Peasant Leagues stressed the need for a direct action approach, with the slogan 'Agrarian reform: by law or by force!' In the end, the congress declaration supported the more radical approach to agrarian reform advocated by the Peasant Leagues (Costa 1993; Stedile 2005).

President Goulart, the first lady, and the prime minister attended the congress, establishing for the first time a public connection between the social movements of the countryside and the executive branch of the federal government (Costa 1993; Welch 2010). Goulart's government, in spite of its leftist populist orientation, hesitated in seeking to fulfill the primary goal of the congress, radical agrarian reform. The 1946 constitution permitted expropriations of private properties, but the land had to be paid for in advance and in cash, making expropriations impossible as no federal funds for such payments had been appropriated. This situation resulted in promoting the secondary demand of the event that of legally authorizing the organization of peasants, including their unionization. Thus, legally regimenting the rural labor movement would become the primary achievement of the congress (Costa 1993; Welch, 2010).

For the next 3 years, the demands for agrarian reform and rural unionization topped the list of questions debated nationally. In 1962, the minister of labor permitted the recognition of hundreds of new rural workers' unions. Later in the year, Goulart established the Superintendent of Agrarian Policies, in order to promote the formation of unions and administer the implementation of agrarian reform. In March 1963, Congress approved Brazil's first comprehensive rural labor law, the Rural Labor Statute. ${ }^{2}$ In accordance with the statute, a vigorous campaign to organize rural labor unions ensued. The process emphasized the struggle for peasant civil rights and the improvement of working conditions through application of the law. The benefits of institutionalization and the force of the communist organizers caused many peasant leagues to transform themselves into local unions, deepening an organizational crisis already apparent in 1962. Increasingly influential was the idea that a strong unified rural labor movement had to be established to overcome the resistance of rancher, planter and landlord groups to changes in land and labor law, especially a constitutional amendment. At the end of 1963, delegates from newly formed state federations established CONTAG, the movement's maximum entity (Welch 1995; Ricci 1999).

Thus, strategists privileged expansion of the peasant union movement as fundamental to weaken the power of the rural oligarchy, creating more support for the election of candidates committed to the basic reforms deemed necessary to stimulate economic development - the major project of Goulart and his Brazilian Labor Party. The representation of rural unionization as a step toward radical agrarian reform (Pinheiro Neto 1993) provoked planter, rancher and miller groups to support unfolding plans for a military coup designed to unseat Goulart (Welch 1995). Two weeks after a public speech in March 1964, in which Goulart proclaimed agrarian reform as part of his presidential plan of action and his intention to distribute land to peasants along federal highway corridors, an armed assault, supported militarily and diplomatically by the United States, ended the Goulart government

\footnotetext{
${ }^{2}$ Established as Public Law 4,214 in March 1963, it was built on existing rights to create a specific law aimed at rural labor, establishing a corporatist system of syndical organization that was similar to those already used by some urban workers since the 1940s. It was amended and substituted by law 5,889 in 1973.
} 
and its national reform project (Ferreira 2011). Peasant mobilization, supported by the executive branch, was a major reason for the coup (Welch 1995).

Within some 7 months of the coup, the dictatorship formulated an agrarian reform law, the Land Statute, to honor Brazil's promises to the US government, especially the Alliance for Progress accord, which established passage of the statute as a prerequisite for Brazil to receive a large, multifaceted United States Agency for International Development mission. Arguments in favor of the statute emphasized it as an instrument for securing the predominance of middle class farmers (Bruno 1995; Stedile 2005). ${ }^{3}$ According to advocates, the statute would generate plans for eliminating the two most prevalent farm categories - the inefficient minifundio and unproductive latifundio - by stimulating the productivity of the most enterprising farmers through mechanization and chemical inputs.

In practice, the Land Statute caused the elimination of millions of smallholders and helped consolidate large landholders through favoritism. It presented a new standard for land use, replacing the term 'social welfare' with 'social function'. It specified the terms of land expropriation and structural reform in areas of conflict, but repression and demobilization initially left the peasant movement with too little force to pressure the government to implement this part of the law. To the contrary, the agricultural elite and influential investor groups pressured the dictatorship to utilize the law to eliminate 'unproductive units' by subsidizing existing 'productive units' as well as [encouraging? subsidizing?] to take over peasant land, expanding the agricultural frontier and 'modernizing' some production processes (Minc 1985; Gonçalves Neto 1997; Silva 1998). Although they eliminated the Superintendency of Agrarian Policies, many of its functions were maintained by dividing them into two new agencies: the Brazilian Agrarian Reform Institute and the National Agrarian Development Institute. ${ }^{4}$

In addition to the supposed paradox of the dictatorship's promulgation of Brazil's first land reform law, the military regime also maintained the recently passed farm labor law. Its corporatist nature was similarly appreciated as useful by the dictatorship. Thus, instead of eliminating CONTAG and the rural labor unions, they promoted interventions and sought to change the movement's identity to support the regime's agricultural modernization project. The military coup persecuted communists and progressive Catholics, replacing them with allies, including some military officers and, in the case of CONTAG, personnel from the conservative wing of Catholic social action groups. The regime deposed CONTAG's president, the Communist Party's Lyndolpho Silva, and replaced him with José Rotta, a conservative Catholic merchant and farmer from São Paulo state who had proved effective in organizing rural worker unions in collaboration with planters (Ricci 1999; Welch 2010).

While the ferocity of the repression cannot be denied, the literature too often emphasizes the coup as a dramatic transition in the story of the peasantry's political consciousness and the deposed government's commitment to agrarian reform. It is as if the coup leaders were correct in arguing that Brazil was on the cusp of an agrarian revolution. Evaluating the veracity of this argument depends on two very questionable 'ifs'. First, if Julião's peasant leagues had not been suppressed by the coup, a popular movement would have grown and

\footnotetext{
${ }^{3}$ Established by decree law 4,504 in November 1964, it had been debated for many years, but the project finally approved had been produced by a conservative think tank allied with coup conspirators. It suffered various revisions before being approved by the regime leader, Marshal Humberto de Alencar Castelo Branco (Bruno 1995).

${ }^{4}$ In 1970, these two institutes were merged to form the National Institute for Colonization and Agrarian Reform (INCRA, in its Brazilian acronym), which still functions today.
} 
forced agrarian reform policies to be more radical and change the Brazilian agrarian structure. This seems unlikely given the fact that nearly 2 years before the coup, Julião and the leagues had been marginalized from public policy debates, a fact only confirmed by their total absence from the CONTAG leadership posts at the end of 1963. Second, if Goulart had not been overthrown, his government would have adopted agrarian policies more favorable to small farmers, including a radical agrarian reform law. Goulart's most radical proposal was a constitutional amendment that would have eliminated the need to pay cash when expropriating private land. Without that change, his proposals would have been impossible to implement, since they required peasants to purchase their plots. Moreover, plans for many mega-projects critiqued today as socially and environmentally destructive agribusiness ventures - such as the occupation of western lands by large-scale grain operations - were written during Goulart's term in office.

Finally, this period shows how CONTAG's very birth defined the 'tight spot' between tendencies to negotiate with authorities and opposition to/demands against established authority. As a public-private entity, CONTAG depended on the state and suffered interventions it could not resist. Given these examples and the regime's support for the rural labor and land statutes, there is good reason to argue that continuity rather than change should be emphasized in understanding this history.

\section{Rural unions and the land under the statute regime (1964-1988)}

The military-civilian regime that dominated Brazil from 1964 to 1984 used the rural land and labor statutes to establish and implement agricultural policies described by many as 'conservative modernization' (Moore 1966; Domingues 2002). For many peasants, however, the application of the dictatorship's policy proved more brutal than conservative - a 'painful modernization', according to agronomist José Graziano da Silva (1982) - and more traditional than modern, as it only intensified the arbitrary power of landlords.

In February 1965, the dictatorship issued an edict that altered the farm labor law to permit only one Sindicato do Trabalhador Rural (Rural Worker Union) per municipality - thus identifying all categories of peasants as 'rural workers'. This reflected an attempt by the regime to regiment the rural laboring classes, paving the way for the transformation of smallholders into rural proletarians by imposing a unitary formal identity on the rural poor (Grzybowski 1991).

Thereafter, the dictatorship invested heavily in agricultural modernization by capitalizing large estates through allocations of financial resources, especially agricultural credit and other fiscal incentives, creating conditions for the use of innovative inputs (from hybrid seeds to chemical fertilizers) and mechanized agricultural implements (from chainsaws to harvesters). On the frontiers of agricultural expansion, the regime granted financial privileges to urban entrepreneurs to stimulate the purchase of large tracts of undeveloped land (Oliveira 2010), and provided them with research and technical assistance that reinforced historic trends of planting monocultures for export (Gonçalves Neto 1997). 'Modern' quality and uniformity standards also weighed heavily on small-scale growers of cacao, coffee and other crops, for whom the dictatorship provided no subsidies or technical support. These processes deepened land concentration and forced the displacement of millions of peasants, causing them to either move to urban areas or participate in projects designed to colonize less desirable parts of Brazil's vast hinterland. In fact, these policies expelled more than 25 million peasants from their homes in the 1960s and 1970s (Martine 1987). 
Many of these new migrants sought work in the newly forming agro-industrial centers in the central-south region, especially as cane cutters on the sugar plantation and mill complexes of São Paulo state. But the situation of these peasants, forcibly uprooted and transformed into rural proletarians, had become so sorry that a new expression was invented to describe them as a 'cold lunch' (bóia-fria), reflecting working conditions that caused them to leave home before dawn, carrying with them a pot of hot food that turned cold in the fields before the mid-morning lunch break. More than 100,000 boias-frias lost labor law protections in 1965 when the São Paulo-based industry determined that the law applied only to industrial workers in their sugar mills. It took nearly 10 years to legally reverse the cane-cutter exclusion (ESP 1973, 16), and by that time the industry had developed new ways of exploiting these workers. Instead of contracting the cutters directly, the industry stimulated the creation of a third-party system of labor cooperatives and labor contractors, called 'cats' (gatos) for their sly recruitment strategies. These techniques merely served to disguise the employment relation and allow the industry to avoid the added legal and financial obligations of employers under rural labor law. These tactics also denied workers the possibility of joining unions to defend themselves, turning the boiafria into a new form of modern slavery (D'Incao 1975).

In the political sphere, the dictatorship produced a new constitution in 1967, which suspended national elections, and in 1968, it suspended Congress and intensified persecution of opposition groups, especially left-wing and popular leaders, violently smashing any form of dissent (Alves 1984). According to political scientist José Murilo de Carvalho (2004), besides the repression, the dictatorship also adopted a strategy of rural populism, looking for support among planters and peasants alike. The strategy was two-pronged, with modernization depicted as a nationalist economic development project and rural unionization represented as a means to advance the social rights of peasants. As Carvalho comments (2004, 172): 'The initial repression exercised against these unions, in addition to the assistance tasks now assigned to them, contributed to reduce their political combativeness and offered political dividends to the military governors', including electoral support. These strategies provoked internal conflict within the rural labor movement, but the repression did not cause the unions to break away from the corporatist dilemma. While these strategies provoked dependency on state benefits, the institutional relationship seemed important to maintain the unity needed to resist repressive times (Grzybowski 1991).

On the other hand, to avoid alienating the landlords who resisted both the labor and land statutes, the regime removed 'agrarian reform' from its first national development plan, which oriented economic policy from 1972 to 1974 (Carvalho 2004; Gonçalves Neto 1997). The plan crowned the achievements of President Medici, who ran the country during the bloodiest years of repression (1969-1974). Paradoxically, these 'heavy years' of dictatorship saw dramatic growth in rural unionization (Maybury-Lewis 1994; Houtzager 2004). In 1968, a rival faction of militant labor unionists took control of CONTAG, led by a skillful young sugarcane cutter from Pernambuco, José Francisco da Silva. Silva first became a union official by working as one of a team of 'field' representatives on a sugar plantation near Nazaré da Mata. Under threat of intervention, the union local strived to express its commitment to bread-and-butter questions while decentralizing power to protect its autonomy by promoting greater grassroots agility in resolving labor disputes in the field. From field delegate to local union president, Silva quickly rose to lead the state federation. The dictatorship, with its intervention in the confederation, had centralized power in the director. Silva's allies used the centralized structure to win majority support for his presidential bid from the small group of delegates permitted to vote. In the next few years, Silva and allies sought to revive CONTAG from the grass roots with an aggressive 
national union organizing campaign (Maybury-Lewis 1994; Ricci 1999; Medeiros 2012). In 1971, the dictatorship tried to co-opt the initiative with the Rural Fund (FUNRURAL, in its Brazilian acronym), its project for making the unions administrators of this rural social welfare program. Euclides Nascimento, a historic Pernambuco union leader, called the fund a

problem ... dropped inside the union movement. It anesthetized the movement. Many local rural unions fell into this trap, losing their line, the line of combativeness, fighting for land and for rights, and went over to attending the affairs of doctors, dentists, retirement. (Maybury-Lewis 1994, 76)

All the same, the number of rural labor unions in Brazil more than doubled, from 938 in 1967 to 2068 in 1975 . The number of workers represented thereby grew from around 1 million to more than 4 million, and continued to grow at a somewhat slower rate throughout the remainder of the dictatorship. In 1986, CONTAG's 2856 affiliated unions reported a membership total of nearly 10 million peasants (Maybury-Lewis 1994). This reinvigorated rural labor movement had to work to keep the dream of land reform alive in Brazil. According to rural sociologist Leonilde Medeiros (1993), CONTAG reinvented agrarian reform as a common goal to unify diverse rural struggles and demands. Anthropologist Moacir Palmeira and economist Sérgio Leite $(1998,132)$ similarly wrote that 'the workers were maturing into their own project of agrarian reform that counter-posed the policies elaborated by the military government'. Despite CONTAG's coordination of various conflicts under this unifying banner, Medeiros notes that 'the expropriation of land for social interests did not unfold as suggested by the Land Statute, except in a few specific settings where collective actions helped guarantee the permanence of workers on the land' $(2012,706)$.

CONTAG based its agrarian reform line on demanding recognition for the rights expressed in the land statute, holding the regime to the legal standards it represented for itself (Minc 1985; Martins 1988; Pereira 2005). In the context of the political persecution then suffered by activists of all stripes, union leaders considered the defense of the regime's own laws as the most sensible form of militancy (Palmeira and Leite 1998). While union leaders viewed the 'politics of the possible' option as a cost-effective approach to opposing regime policies (Maybury-Lewis 1994), the rural fund and land statute could be used to address only a small portion of the enormous challenges peasants faced. ${ }^{5}$ To help resolve problems the unions seemed unwilling or incapable of addressing, the peasantry sought help from other institutions, especially the Roman Catholic Church, which responded in 1975 by joining with the Lutheran Church to found the Pastoral Land Commission (CPT, in its Brazilian acronym).

The CPT embraced the peasant cause as its mission and eventually became involved in the movement to revitalize rural unions, making it highly relevant to a discussion of rural labor unions and land struggle (Almeida 1991). According to CPT insider and sociologist Ivo Poletto, the priests and pastors involved created the land commission based on the 'necessity of overcoming isolation, of improving the knowledge of reality, and making the Amazonian pastoral work more dynamic' $(1985,38)$. Like CONTAG, the land commission initially raised the agrarian reform flag 'to support the demands of rural workers for a

\footnotetext{
${ }_{5}^{5}$ Ricci (1999) argues that the rural union movement lost its way in the 1970s, when it privileged land reform despite the fast growth of farm labor membership more interested in wages and conditions. Ricci claims this failure to represent the rural labor voice made CONTAG ill-prepared to head off the formation of rural social movements in the 1980s.
} 
land reform within the letter and spirit' of the land statute (CPT 1983, 76), but did so criticizing the rural labor unions as being too passive in pursuing similar goals.

Despite the use of Marxist texts and ideas like class struggle at the grassroots level, the Catholic Church hierarchy continued to oppose communists in positions of authority. The church challenged established CONTAG rural union leaders not merely to replace supposedly co-opted union officers, who accommodated the dictatorship, but also to challenge officials with links to the Communist Party. The presence of a band of some 60 communist guerrillas in the Amazonia diocese of Bishop Pedro Casaldaglia had helped him convince the church to support founding the CPT, especially after military operations began to repress the incipient movement, causing the displacement, internment and death of an untold number of peasants. Thus, the Catholic Church's confrontation with communism added fuel to the fire as the CPT sought to strengthen radical grassroots leadership among peasants. The development of these leaders was accomplished gradually through varied forms of meetings, advocacy, classes and popular education techniques. Those identified as potential leaders were encouraged to form opposition slates to take control of their unions (Maybury-Lewis 1994; Balduíno 2004; Canuto 2006; Welch 2006b).

In the 1970s, one alleged Communist Party militant in the rural labor union structure was Roberto Toshio Horiguti, president of the São Paulo state federation of rural unions and a vice president of CONTAG (Aly Junior 2013). In 1979, he participated in a conference on the land statute sponsored by the Brazilian Agrarian Reform Association (ABRA, in its Brazilian acronym). ${ }^{6}$ The ABRA conferees concluded that the land law had been implemented 'only in ways that interested the owners ... in benefits that stimulated ranchers and enriched the large landowners' (Horiguti 1979). Horiguti noted the misuse and subversion of the law, asserting that the union movement was 'a constant organ of pressure' for implanting 'agrarian justice' by 'proclaiming the reign of law' (Horiguti 1979, 23). For activists in the unions and the CPT, fulfillment of the land statute actually meant the opposite of what happened in practice. For the dictatorship, the law served to justify agricultural 'modernization', but the unions and CPT emphasized the need to break up large estates and distribute land to small-scale farmers (Silva 1971; Minc 1985).

In the late 1970s, the frequency and intensity of strikes in the cities and countryside grew, with metalworkers setting the pace in industrial centers and sugarcane cutters leading the way in agriculture with their demands for better working conditions and pay (Siguad 1980; Alves 1984). In 1979, an amnesty law allowed the return of exiled political leaders and activists and stimulated the re-formation of leftist political parties. The union movement played a central role, with CONTAG supporting the legalization of the Communist Party and the CPT participating in founding the Workers Party (PT). In the context of a political 'opening' promoted by the dictatorship, the Communist Party and PT represented two different nodes in the network of the democratic left. With its position supporting the autonomy of working-class organizations, the CPT contributed to forming the new union movement, as well as other popular and political organizations (Poletto 1990). In 1981, it played a key role in resisting Communist Party attempts to restore 'union unity' under communist political leadership at the crucial National Working Class Congress (CONCLAT, in its Brazilian acronym; Thomaz Junior 2002; Medeiros 2012). ${ }^{7}$ In 1983, the CPT also helped organize the Unified Workers' Central (CUT, in its Brazilian

\footnotetext{
${ }^{6}$ Founded in 1967, ABRA gradually took the form of a 'think tank' dedicated to agrarian reform advocacy, and was led by José Gomes da Silva, who carefully constructed an alliance with the rural labor movement, including CONTAG officers, CPT figures like Poletto and other rural leaders.
} 
acronym) and, in 1984, the MST, thereby escalating the ongoing tension between the CPT and CONTAG (Sauer 1996).

In the process of rebuilding old political parties and building new popular organizations, the broad sources of rural mobilization kept agrarian issues and demands for land on the political agenda. Despite their tensions, CUT, CONTAG and CPT were united in supporting agrarian reform, creating in 1982 the National Agrarian Reform Campaign, with the participation of ABRA and the Brazilian Social and Economic Analysis Institute (Palmeira and Leite 1998). Popular mobilization for political freedom 'raised expectations regarding the possibility of agrarian reform' as part of the political process of democratization that helped provoke the military to step down from power at the end of 1984 (Deere and Medeiros 2008, 83).

In January 1985, José Sarney - the first president democratically selected since 1961 took office, and land reform advocates such as CONTAG lobbied for dramatic changes through the creation of a national agrarian reform plan, a policy orientation instrument originally called for in the land statute. Despite sugarmill owner and planter protests, Sarney appointed as president of INCRA ABRA's coordinator, José Gomes da Silva, who embraced the task of preparing the plan (Minc 1985). Silva $(1989,14)$ believed that the laws were in place to allow the executive branch 'to initiate a change in the agrarian structure in Brazil', requiring 'only an indispensable decision, will and political action' to put such a plan in place. He believed that the break-up of unproductive estates and the establishment of small farms thereon would serve to benefit not only the peasantry but the entire political economy, with gains to be realized in the marketplace and public square, due to the enhanced economic and political participation of peasants (Silva 1971, 1987).

Launched in May 1985, at CONTAG's fourth national congress, the agrarian plan promised to set aside land and settle 1.4 million families in 4 years (Sauer 2002). As soon as Sarney signed the plan in October 1985, Silva - whose health was not good left INCRA triumphant. But landlord groups worked tirelessly to undermine the plan, and Sarney lacked the important political will to challenge them sufficiently (Silva 1987). The agrarian plan failed to achieve its goals and in 5 years, the Sarney government settled only 125,000 families, not even 10 percent of the projected total.

In the midst of the struggle to implement the agrarian plan, CUT created a leadership post on its board that would form the central's National Rural Unionization Department (DNTR, in its Brazilian acronym). From 1986, the union central invested in a grassroots rural unionization campaign meant to gain control of CONTAG (Ganzer 1997; Medeiros 2012). The struggle for control of peasant unions focused on forming competing slates to dispute official elections (Iokoi 1986; Medeiros 2012). Only by controlling a majority of rural worker unions in each state could CUT take control of the state federations, which then would allow it to gain control over the confederation. Ironically, this meant that CUT had organized itself to dominate a system it had initially opposed, the corporatist structure that privileged unified representation over union autonomy (Ganzer 1997; Ribeiro 2013). Theoretically, unity suppressed rank-and-file demands, whereas autonomy stimulated more aggressive grassroots activism, promising to more thoroughly represent the peasantry. CONTAG was not a still-life, however, so the confederation stepped up its union organizing activities while, starting with the CONCLAT in 1981, it became involved in

\footnotetext{
${ }^{7}$ According to Poletto $(1990,19)$, the final document of the 1986 general assembly overemphasized the CPT's support to the organization's 'conditioning the "value" of the struggle for land to the discovery of the political importance of the unions' and party's organizations'.
} 
founding another 'centralizing' labor institution, reviving the Communist Party's old General Workers Command, where CONTAG's President Silva was made vice president.

In the midst of these union struggles, the inadequate implementation of the agrarian plan led the movements to shift their mobilizations to the fight over the composition of the country's new constitution, in 1987 and 1988. The importance of union politics for Brazil's land reform came into sharp relief during these debates and mobilizations, which deeply influenced the constitution that was promulgated in 1988 and remains in effect today (Sauer 2002). The backdrop for the 1987-1988 constitutional fight includes the membership of CONTAG's president on a commission appointed by Sarney in 1985 to draft a proposal for consideration by the elected delegates of the constituent assembly, which was established in February 1987.

Silva brought to the discussion two important CONTAG documents generated in the context of the confederation's 1985 congress: a list of 10 directives for agricultural policies and a manifesto called The rural workers and the constituent (Silva 1989, 32-34). They demanded laws to facilitate the expropriation of large farms, limit the maximum size of agricultural properties, restore public lands surreptitiously stolen from the state and automatically restrict the property rights of large landlords (defined as those holding more than three 'fiscal modules', 8 where more than 50 percent of the land was left fallow, constituting a failure to fulfill the 'social function' standard of land, as demanded by the 1964 land statute; CONTAG 1985). These labor movement proposals represented an explicit break from 20 years of defending the land statute and insisting on its strict application, as each of these demands expressed a determination to expand its parameters and CONTAG's commitment to defining agrarian reform as a path to constructing a democratic society (Duarte 1998).

By supporting activist opposition slates and land occupations, the CUT's rural department, the landless movement and CPT challenged CONTAG's emphasis on institutional struggle, but found common cause with CONTAG and ABRA in mobilizing to influence the constituent assembly to incorporate agrarian reform. All of the social movements, including the just-born MST, contributed to the popular mobilizations (Fernandes 1996; Sauer 2012; Medeiros 2012). They organized several mass rallies in Brasilia and sponsored national circulation of a 'people's amendment' demanding agrarian reform's inclusion in the constitution. The amendment attracted 1.2 million signatures of support and contributed to ensuring a place for agrarian policy and reform in the 1988 Constitution (Sauer 2012). An article specified the criteria necessary for land to fulfill its 'social function', conditioning the privilege of retaining agricultural land on its productive use as well as respect for labor and environmental laws. The federal government was charged with expropriating for agrarian reform purposes the lands of those landowners who violated these conditions (Brazil 1988; Silva 1989; Sauer 2010).

The rural social and labor movements were not alone in their attempts to mobilize pressure to influence and participate in the constitutional process. Landlords also got organized. The rural employers' union counterpart to CONTAG as well as both traditional and new groups of planters and landlords, including many cattle ranchers who then established the Rural Democratic Union (UDR, in its Brazilian acronym), formed the so-called Broad Agriculture Front to more aggressively defend landlord interests in the constituent assembly

\footnotetext{
${ }^{8}$ A 'fiscal module' (modulo fiscal) is a Brazilian legal term defined in the 1964 land statute as an area of land sufficient to support a family. The calculation of its size varies from municipality to municipality, depending on agricultural conditions.
} 
(Silva 1989; Simon 1998). In the intense dispute over each word of the constitution, landowners imposed their interests through an additional article that excluded 'productive property' from the expropriation process. Moreover, they succeeded in blocking the inclusion of popular demands, like limits on the size of rural properties and punitive, uncompensated expropriation. As experience later demonstrated, the implementation of the constitution's agrarian reform policy chapter privileged productivity as the main criterion taken into account to evaluate if landed property meets social function criteria, becoming one of the greatest impediments to the fulfillment of the agrarian reform goals established by those fighting to represent the peasantry in Brazil (Fernandes, Welch, and Gonçalves 2012; Sauer 2013).

\section{Rural unions and land struggle under Constitutional law (1988 to 2013)}

At the end of the 1980s, after the constitutional debates, CONTAG continued to make agrarian reform a priority. However, several changes can be charted in its form of mobilization and struggle for land. A variety of factors affected change in the confederation's approach to this goal. Highlighted below are four key processes: (1) the influence of occupations as a primary form of struggle; (2) the involvement of the union base (locals and state federations) in direct-action land struggle, including the organization of land occupations in some states; (3) CONTAG's 1995 affiliation to CUT and that movement's emphasis on direct action; and (4) the government's expropriation of land, especially after social movements found the leverage to force a response from President Fernando Henrique Cardoso in the mid-1990s. Even while CONTAG moved closer to the MST in some ways, it defined a distinct approach that guaranteed its negotiating credentials with authorities.

Into the 1990s, rural unions continued to be 'a necessary reference and an effective support system' for almost all of the struggles in the countryside (Grzybowski 1991, 62). Challenged by a growing landless movement, various unions and some state federations in the Northeast, North and Central-West regions of Brazil began to organize peasant families to occupy land in order to demand its expropriation for agrarian reform settlements (Sauer 2002). This direct union involvement in such grassroots actions gradually altered CONTAG's internal understandings and deliberations, leading the peasant labor movement to heighten its call for agrarian reform. Given the nature of occupations as encampments involving entire families, CONTAG also gained experience mobilizing women and children, not only predominantly male workers or heads of families, adding further complexity to its identity and practices (Medeiros 2012).

During the 1990s, the effects of these developments on political change within CONTAG - including official recognition of occupations as legitimate and decisions to encourage the participation of locals in mobilizing families - can be detected in the way its organizational documents changed from one congress to another. In 1991, for example, CONTAG's fifth congress reaffirmed that agrarian reform should be put in place through 'radical land redistribution and the formation of settlements of rural workers on land that is economically viable' (CONTAG 1991, 64). The congress documents further stressed that agrarian reform policy should have as its objectives: (1) increasing employment in the countryside, (2) reducing rural exodus, (3) increasing food production for the internal market, (4) increasing rural worker salaries and (5) decreasing regional inequality (CONTAG 1991). Theoretical and political understandings developed in prior decades strongly influenced these objectives, including notions of the 'functionality' of small-scale production, which provided the majority of cheap food for the urban population (Sauer 2002). 
However, until the mid-1990s, the rural union movement's direct land actions had generated few concrete results, with some state federations promoting land mobilizations in Goiás, Minas Gerais and Pará (Medeiros 1993). Direct-action advocates discussed manifestos, promoted new leadership and organized land struggle support mechanisms (CONTAG 1991). However, the union movement faced many difficulties putting these political decisions in practice and mobilizing families to occupy land.

The final document of the next CONTAG congress clearly reflected these barriers (CONTAG 1995; Medeiros 2012). Internal and official evaluations recognized the mismatch between political decisions and the practices of the union movement in the struggle for land. Officially, it admitted that agrarian reform objectives had been 'placed as a priority in union documents and in union encounters, however, these goals were only put into practice by a small portion of local unions, as these unions were confronted with other struggles' (CONTAG 1995, 43). Indeed, the majority of union work involved dealing with the problems of salaried farmworkers and small farmers. In terms of agrarian reform, the principal novelties of this period included the recognition of occupations as legitimate political actions 'to guarantee access to land and production', and the leadership's willingness to critically evaluate the organizational challenges the unions faced to participate in this movement (CONTAG 1995, 43).

From 1995, when confederation delegates voted to affiliate with CUT, leaders essentially endorsed the land struggle then practiced by some union locals and state federations. Given the direct-action roots of the unionists who participated in CUT's rural department, the final merger between CONTAG and CUT promised to reduce internal disputes and increase the confederation's investment in achieving objectives like agrarian reform (Medeiros 2012). ${ }^{9}$ This reflected the growing participation of the local and state federations that supported direct action and reasserted the importance of struggling for agrarian reform through the organization and mobilization of landless rural workers (CONTAG 1995). These actions represented a significant break with the legacy imposed by the dictatorship of confining union practice to the legally proscribed parameters that long limited the unions to representing salaried agricultural workers and small farmers, despite outreach to boias-frias and other underrepresented segments of the peasantry.

From the mid-1990s, CONTAG prioritized land occupations as a means of achieving agrarian reform goals, especially with the attention the national media gave this form of mobilization and struggle once the MST had established itself in São Paulo's Pontal do Paranapanema region. As Brazil's richest state, a leading commodity producer, headquarters not only to many landlord organizations but also to the banking industry, the seeming contradiction between advanced capitalism and peasant struggle fascinated the press. Initially, heightened press coverage built public sympathy for the landless and increased pressure on the labor movement to express itself regarding the issue. The press incited the public to expect the rural labor movement to be involved in the land struggle (Coletti 2002; Sauer 2002; Welch 2009a). Although statistics on the involvement of diverse

\footnotetext{
${ }^{9}$ Two internal disputes continued to influence the peasant labor movement. These were the 1989 founding of the Federation of Rural Employee Unions (FERAESP, in its Brazilian acronym) in the state of São Paulo, and that of the Federation of Family Farm Workers (FETRAF, in its Brazilian acronym), both affiliated to CUT. FERAESP militated mostly among seasonal cane cutters and fruit pickers, increasingly supporting them in direct-action land struggle. Founded in 2001, FETRAF-Sul remained a regional organization in the southern state of Santa Catarina until 2005, when it expanded activities into other states, stimulating its transformation into a national organization.
} 
organizations only began to be gathered in 2000, they consistently placed CONTAG as second only to the MST in terms of the entities identified with the land struggle. From 2000 to 2012, CONTAG led 519 land struggles involving more than 53,000 families, in comparison to the 2701 settlements involving more than 450,000 families led by the MST (NERA 2013, 30).

This defense of agrarian reform, and the increasing involvement of CONTAG-affiliated unions in the struggle for land, led the confederation to participate in the National Forum for Agrarian Reform and Justice in the Countryside (FNRA, in its Brazilian acronym). Established in 1995, this forum eventually congregated some 40 entities and movements, such as the CPT, MST, CUT and other grassroots, labor and non-governmental organizations. Initially, its agenda was consensual, reflecting shared criticisms of the land-tenure policies of President Fernando Henrique Cardoso. Under this pressure, the Cardoso government deftly shifted strategy, committing itself to settle hundreds of thousands of landless peasants and establish a separate ministry to handle the challenge, while also working to disintegrate the unity of the forum for agrarian reform by embracing CONTAG and isolating the MST. Consistent with the administration's acceptance of neoliberal Washington Consensus policies, President Cardoso aligned the government with World Bank initiatives to implant market-based agrarian reform policies. By gaining CONTAG's endorsement and participation in the implementation of these policies, the Cardoso administration significantly fractured the cohesion of the forum (Sauer 2012; Medeiros 2012).

In this period, CONTAG adopted the 'family farmer' concept, which had already been developed by international institutions like the Food and Agriculture Organization of the United Nations (FAO; Lamarche 1993; FAO/INCRA 1994). ${ }^{10}$ For CONTAG, the term was quickly used as a substitute for 'small production' or 'small farmer' (CONTAG 1991) - and even the slightly older generic term 'rural worker' (Palmeiras 1985). The change in terminology indicated changes in the labor movement's subsequent theoretical formulations and negotiation agendas, especially CONTAG's approach to agrarian reform. In 1995, the confederation first applied the term to identify the subject of CONTAG's new sustainable rural development policies (CONTAG 1995, 51). From this basis, CONTAG broadened its demands and formulated model agricultural policies for 'family farmers' (CONTAG 1997; Sauer 2002).

The reorientation became apparent when CONTAG launched a series of protests initially called National Days of Struggle, which in May 1995 gained the name 'Brazil's Cry of the Land' (Grito da Terra Brasil; Grito 1995). Noteworthy is the fact that at this time the MST lent its support to policies designed to favor 'family farmers', as it was one of the top-listed signers of the original manifesto. ${ }^{11}$ In August 1995, the government responded to the demands of Grito organizations by establishing the National Program for Strengthening Family Farmers (PRONAF, in its Brazilian acronym; Schneider, Mattei, and Cazella 2004). CONTAG considered PRONAF a major political victory, despite the program's restricted credit lines and its initial use only by family farmers in the South of Brazil. For CONTAG, this was an important victory because it was the first government program created exclusively for 'family agriculture', recognizing and

\footnotetext{
${ }^{10}$ For some authors, the family farmer idea came to be seen as an important means for defusing a growing international anti-globalization peasant resistance movement, especially the growing alliance of rural social movements in the Via Campesina (Fernandes 2002; Borras, Edelman, and Kay 2008). ${ }^{11}$ The manifesto of 1995 Grito was signed by several agrarian, indigenous and fishing movements and organizations, including CUT and MST, and stressed the need for the government to design a 'Differentiated Agricultural Policy for Family Farming' (Grito 1995, 4).
} 
'making official' the existence of this 'social category' (Schneider, Mattei, and Cazella 2004, 1).

On the other hand, despite the appearance of victory, some critics of CONTAG's 1995 theoretical formulations questioned the ways in which the emphasis on family farming began to dislodge agrarian reform as a top priority (thus reducing the importance of land struggle). In many documents, the government used terms such as 'expansion', 'extension' and 'strengthening' of family agriculture as euphemisms for increasing the productivity of existing farms, rather than for increasing the number of farms and farmers. Agrarian reform meant breaking up large estates and distributing these lands as well as public lands to the landless, thereby producing more farmers (FNRA 2005). Excessive preoccupation with 'family farmers' risked diluting long-established dichotomies that cast the world in black-and-white hues of either/or counter-positions, especially between the struggle for land and the growth of family farming (Carneiro 1997; Sauer 2002; Paulino 2014).

An increase in the number and intensity of rural conflicts also influenced CONTAG to revise its theories and tactics. Two massacres in the mid-1990s received the most attention. On 9 August 1995, gunmen killed 12 landless campers in Corumbiara in Rondônia state and, on 17 April 1996, police massacred 19 MST protesters and permanently crippled 50 more in Eldorado dos Carajás in Pará state. The latter had the greatest national and international repercussions, influencing rural land and labor disputes and policies into the tweny-first century (Sauer 2010; Medeiros 2012). These violent episodes, together with the long MST march to the nation's capital in 1997, and a burst of land conflicts all over the country, kept the theme of agrarian reform on the national agenda, including CONTAG's agenda. These developments also forced the administration of President Cardoso to formulate an agrarian reform program and create, in 1996, a cabinet post for land policy that served as the basis for creating a separate ministry in 1999, today's Agrarian Development Ministry (MDA, in its Brazilian acronym). These entities became responsible for administering INCRA and PRONAF, and developed a variety of initiatives related to agrarian issues, including a project to settle 400,000 landless families in 4 years (Deere and Medeiros 2008, Sauer 2010).

In 1998, CONTAG hosted its seventh national congress and consolidated its proposal for an 'alternative project of rural sustainable development' based on strengthening family farms. Consequently, the defense of agrarian reform lost additional political space in the union movement because it was not 'taken as an end in itself', but rather as 'an essential part of constructing a strategy of development, centered on expanding and strengthening family agriculture' (CONTAG 1998, 72). Its leaders did not see any contradiction in simultaneously adopting policies promoting 'the direct participation of union entities in the coordination of occupations and the accompaniment of these processes, administratively and judicially' (1998, 72) and calling for affiliated union locals to focus their energy primarily on already expropriated areas - in other words, the development of the settlements as part of the consolidation of family agriculture (CONTAG 1998; Sauer 2002).

Reading between the lines of these documents, one can reflect on the pre-coup tensions between Communist Party militants and Catholic priests. The militants provoked strikes and the priests privileged institution building. In 1998, a CONTAG increasingly controlled by delegates representing CPT and CUT opposition slates hewed more toward the Catholic legacy. Rather than stimulating land occupations, CONTAG directed union officers to preoccupy themselves more with probing the 'multiple possibilities for and barriers to forms of organization and production' and the 'economic benefits' of settlements (CONTAG 1998, 76). These concerns had two principal foundations: the new family farm theoretical reference and settler demands. In fact, the number of families settled by the agrarian reform 
initiatives of the Cardoso administration had grown greatly, demanding greater attention to their specific sustainability problems and the need to enhance public policies supporting settlements.

For CONTAG, as well as the government, the family farmer concept provided a useful focus for exploring policy options for settlers. Settlement families linked to the labor movement began to discuss their demands for credit, technical assistance and the organization of production, commercialization, education, health and such through the decision-making apparatus of the unions. They generated new perspectives such as the affirmation that the implementation of public policies for settlements should not be restricted to the mere distribution and ownership of land' (CONTAG 1998, 75). Rather, the agrarian reform settlement projects should be governed by a set of public policies leading to family farmers' agricultural productivity and profit.

In this period, CONTAG made several critiques of the Cardoso government's policies, especially its adherence to various neo-liberal theories, including the minimal, selling off state resources and decreased spending on agricultural programs. In addition, CONTAG joined many other social movements and entities in criticizing Cardoso for a series of anti-land occupation orders that his government began to issue in $1997 .{ }^{12}$ These decrees sought to curtail the actions of rural social movements, as they transformed land struggles into criminal acts and prohibited INCRA from evaluating the agrarian reform expropriation suitability of land that had been occupied. Arguably, these measures ended 'once and for all the possibility that occupations would lead to expropriation' (Deere and Medeiros 2008, 88) by attempting eliminate the political pressure caused by land occupations. While occupation had long served as the landless movement's most effective tool for advancing the cause of agrarian reform, the labor movement came late to the tactic and, despite its discourse against criminalization, its actions in favor of the government's family farm policies moved CONTAG further away from concern over the issue. In spite of these changes, some CONTAG-affiliated unions remained involved in land struggles from 2000 to 2012, organizing more than 1000 families in 14 occupations, in comparison to the nearly 14,000 families the MST led in 108 conflicts during this recent period (NERA 2013, 31).

As shown, the adoption of the family farm concept as both a theoretical orientation and a political identity required for its justification economic results within the agrarian reform settlements. The need for success in the settlements - measured especially by gains in productivity and profits - became fundamental to CONTAG's ability to demonstrate 'the viability of the development of Brazilian family agriculture through the democratization of access to land' (CONTAG 1998, 77). By 2001, it argued that the settlement projects themselves served as 'an effective way to multiply family agriculture' (CONTAG 2001, 34). This justified the demands for public policies concerning credit, investment and technical assistance, and especially the increase in lines of credit from PRONAF (CONTAG 2001). It stressed the protagonism of the productive family farmer as the guarantor of democratization through land access, not agrarian reform in and of itself (CONTAG 2001).

From a political point of view, however, CONTAG continued to affirm agrarian reform as 'a strategic instrument in which to transform Brazilian society' due to its ability 'to destroy the unjust concentration of land, of income and of power by Brazil's political

\footnotetext{
$\overline{{ }^{12} \text { Executive Order } 1.577 / 1997 \text {, reissued under the number 2.027-38 on } 4 \text { May 2000, and definitively }}$ replaced by Executive Order 2.183-56 on 24 August 2001, prohibited 'rural property to be the object of judicial dispossession if subjected to invasion motivated by agrarian conflict or collective land conflict' for two years or more following the end of the dispute (Brazil 2001, Article 4, Section 6).
} 
rural elite' (CONTAG 2001, 12). ${ }^{13}$ It also reaffirmed the importance of occupations as 'essential in guaranteeing the expropriation of rural property and consequently the settlements of rural workers' (CONTAG 2001, 39). Its political formulations at the start of the twenty-first century did not alter the confederation's attachment to the family farmer concept, which its practices and demands aimed to advance by gaining government support for public policies to implement its sustainable rural development project (CONTAG 2001; Sauer 2002).

As mentioned above, to the chagrin of most other FNRA member organizations, CONTAG supported the Cardoso government's 'market-based agrarian reform' initiative (CONTAG 2001). In contrast, the majority of agrarian forum members vehemently opposed these policies. Initiated in 1996, the government's program of buying and selling land, called 'land credit for combating rural poverty', was a 'market-driven agrarian reform' mechanism (Deere and Medeiros 2008; Pereira and Sauer 2011). Despite systematic opposition by social movements, the Cardoso administration continued to make more credit available for buying and selling land, through World Bank programs. Given the MST's vigorous opposition, only CONTAG's support made possible the approval of a second World Bank loan in 2000. This generated more internal conflict within the agrarian reform forum, especially as the loans saddled many families with serious debt problems as they accessed land through these credits (Deere and Medeiros 2008; Pereira and Sauer 2011).

These developments eventually provoked the dissolution of the precariously established forum unity (Wanderley 2003). Geographer Bernardo Mançano Fernandes (2002) argued that the 'family farmer' concept was the root cause of this dissension. According to his interpretation of the concept, the family farmer was a peasant 'metamorphosized' into a small businessman through the exploitation of family and friends. Peasants would have no future unless they embraced the market, either as agribusiness operators or workers. Thus, the elimination of the peasantry was implied by family farm policy like PRONAF. Capitalist experiences based on these ideas, such as the agricultural history of the US, showed how family farmers were aggressively squeezed out of business and eliminated by fewer and fewer families (turned corporations, like Cargill) operating at larger and larger scales (Welch 2005). Thus, the concept represented a threat to the landless and small farmers that groups associated with the Via Campesina sought to represent. They sought to grow and fortify, not reduce and eliminate the peasantry. Thus, at the start of the twenty-first century, the MST and other rural social movements, such as the Small Farmer Movement and Peasant Women's Movement, broke with CONTAG and distanced themselves from the concept partially by contributing more and more to the idea that Brazil's rural poor should be identified as peasants. This is one more reason for opting to recuperate the term 'peasant' from the confusion created by Martins in his 2002 contribution.

As Cardoso's second and last term of office came to a close in 2002, opposition presidential candidate Luis Inacio Lula da Silva (Lula) received overwhelming support from both the rural social and labor movements due to his long personal and political support for radical agrarian reform. To achieve victory in his fourth presidential campaign, however, Lula and his advisors had moved closer to what the Communist Party used to

\footnotetext{
${ }^{13}$ According to the 2001 congress document, 'the democratization of the use and possession of land is an essential means for altering the set of social, economic, environmental, and political conditions necessary to the process of development in the country' (CONTAG 2001, 30).
} 
call the 'national bourgeoisie', including agribusiness firms. Despite the decreasing importance of agrarian reform in Lula's electoral platform, once elected, the Workers Party leader fulfilled his promise to launch Brazil's second National Agrarian Reform Plan at the end of 2003. Following a period of decline in the number of settlements established and families served, Lula's government responded to the pressures of old comrades by significantly increasing the number of settlements created and families settled, especially in 2005 and 2006 (NERA 2013, 19). Like his predecessors, however, Lula no longer had the will to fulfill the ambitious initial goals of his agrarian reform plan. His government added numbers by expanding support for market-based agrarian reform, previously criticized by the Workers Party. In 2006, Lula also signed a law for family farmers, defining them more broadly, including other social groups like the indigenous peoples and maroon communities (quilombolas), who thereby gained access to governmental programs like PRONAF. ${ }^{14} \mathrm{He}$ added more families and hectares by 'regularizing' land occupied but not titled by both peasants and large-scale land grabbers, especially in the Amazon region, where the actions meant little in terms of the redistribution of land (FNRA 2008; Oliveira 2010; Welch 2011).

While CONTAG continued to share with other agrarian movements the demand that Lula increase his commitment to agrarian reform, it tended to maintain political support for Lula and his party. With the continuance of PT rule that came with electoral victory in 2010 for Lula's chosen replacement as president, his former chief of staff Dilma Rousseff, this support translated into a convergence between the government's rural development strategy and some of the policy positions CONTAG had projected in its 1998 congress, especially those emphasizing the consolidation of agrarian reform settlement projects as healthy, productive and profitable for family farmers. But the convergence did not translate into unquestioned support for Dilma, as her near abandonment of agrarian reform provoked factions within the labor movement to increase their criticisms of the government. ${ }^{15}$ CONTAG had in fact become much more complex by the twenty-first century. CUT was no longer the only labor central to which member federations were affiliated, and some of these other centrals, such as Força Sindical, were openly aligned with the PT's leading rivals, especially Cardoso's Brazilian Social Democracy Party (PSDB, in its Brazilian acronym). ${ }^{16}$ In 2012, CONTAG officially welcomed the outreach of rural social movements that sought to include the confederation in a broad alliance of the rural poor to condemn Dilma's policies. In August 2012, CONTAG participated with the MST and other Via Campesina organizations in organizing the so-called Second National

\footnotetext{
${ }^{14}$ Public law 11,326 was approved on 24 July 2006, to establish the concept and directives for the development of national policy for family farmers and their businesses (Brazil 2006).

${ }^{15} \mathrm{By}$ the end of 2012, President Dilma had created one of the lowest numbers of settlements and settled one of the lowest numbers of families per year of any other president since 1988. As her reelection campaign started to gear up toward the end of 2013, she suddenly approved 100 agrarian reform land expropriations, still a very low number.

${ }^{16}$ To explain the contradiction between support and negotiation at this point in history, it is essential to clarify that CONTAG member federations and local unions are affiliated with at least four major labor movement confederations. Each has a distinct relationship with important political parties. While the CUT predominates as an ally of the PT that seeks to provide unconditional support for Dilma, the General Confederation of Workers is aligned with the Brazilian Socialist Party, a friendly rival to the PT, as is the Male and Female Workers Central of Brazil, which follows the line of the PCdoB, which is also a tendentious player in the PT governing coalition. As a PSDB ally, the Força Sindical affiliated members are the most critical of Dilma and supporting the PSDB's candidate for presidency in 2014.
} 
Peasant Congress. ${ }^{17}$ Joint activities continued in 2013, as these same groups pressed for the recognition of the violent repression suffered by the overall peasant movement since World War II. It seemed a new chapter had begun in the collaborative struggle among social and labor movements.

\section{Conclusion}

While agrarian reform remained a labor movement priority, both CONTAG's definition of reform policy (its theoretical approach to the agrarian question) and especially its actions (the practice of rural unionism) changed considerably over the years. This paper argues that, through various socioeconomic and political changes, including runaway land concentration and transitions in and out of authoritarian rule, each of which produced a different land governance regime, the union movement remained committed to an agrarian reform that privileged a concept of land usage defined by individual property rights, family labor and production. This conclusion challenges the one presented in 2002 by Martins, in which he alleged that CONTAG was historically committed to "class struggle against capitalists and landlords' and that the CPT and MST saw 'no need for radical systemic transformation and adhere[d] ... to a communitarian vision in which capitalists and workers enjoy[ed] a tension-free parity of esteem' (327). To the contrary, as we have shown, it was CONTAG that saw little need for transforming the capitalist system and strived to harmonize peasant interests with those who supported market-oriented family farming.

Martins $(2002,324)$ correctly highlights CONTAG as the 'far older grassroots organization... in the Brazilian countryside', which 'has been an authentic "voice from below" ... representing millions of rural workers'. But as Brazil embraced Green Revolution policies and practices, millions of these same rural workers participated in CPT and MST actions in the 1980s and 1990s (Alves 1991; Coletti 2002). With its roots in the Communist Party, class struggle is an important criterion for evaluating CONTAG, but the criticisms of the Communist Party and CONTAG are legendary for downplaying class struggle to build alliances with nationalist ruling groups in order to construct capitalism in Brazil, under the theory that it is a necessary stage to advance toward socialism (Welch 1999). As evidenced above, CONTAG now urges implementation of a rural sustainable development project that it deems 'alternative', without explicit reference to either socialism or structural change.

Historically, the rural labor movement in Brazil emphasized the necessity of implementing an agrarian reform in combination with its defense of expanded labor rights of farm workers. This was CONTAG's main political banner in the years of repression and dictatorship, especially in light of the possibilities provided by the dictatorship's administration of the Land Statute and FUNRURAL. However, in this context, the policy emphasis rarely turned into effective land struggle actions. The confederation only came to officially recognize the legitimacy of land occupations and support their organization in the mid-1990s. Among the many reasons analyzed for this mismatch, we stressed differentiation at the

\footnotetext{
${ }^{17}$ The formal name of this event was the United Meeting of Male and Female Rural Workers and Peoples of the Countryside, Waters and Forests. Organizers reflected on its similarities with the First Peasant Congress organized by the Communist Party in 1961 (see above), but the gathering rejected being called a "congress" as participants did not aspire to deliberate over specific political decisions.
} 
grassroots level in the union constituencies between agricultural employees, small farmers and the landless, and also the organizational structure of CONTAG itself, in which national decisions rarely flow unencumbered to the entire trade union movement and local unions face unanticipated challenges, including legal limitations on their geographical and organizational boundaries.

Despite the conflicts and disputes for leadership in the countryside, the emphasis the union movement has given to agrarian reform since the 1920s has been fundamental to the issue's longevity in Brazil. Especially in the 1990s, CONTAG's continued commitment to agrarian reform, combined with the actions of the MST, ensured its place as a priority concern in Brazil's transition to free market democracy. The labor movement's defense of agrarian reform gave consistency to the political struggle for land, including changes to the federal constitution, land expropriations and the settlement of more than a million families since 1995 (NERA 2013).

The union movement maintained agrarian reform on the national political agenda. Even though it has lost momentum in recent years, due largely to political calculations and policies supported by large-scale agribusiness and fed by dependency on income from agricultural exports, the rural labor movement's combination of protest and negotiation has contributed greatly to institutionalizing not only land reform but also programs of financial and technical support for small-scale family farmers. Despite the ideological debate, CONTAG's family farmers are essentially the same sort of people the MST calls peasants. While criticisms of the labor movement's willingness to collaborate with the government have consistently been raised by supposedly more radical groups, like the Peasant Leagues and the MST, each of these has also sought to win government concessions to help peasants and support their continuity as organizations. Given the union movement's long history of ups and downs, what most stands out is its consistent support for agrarian reform. For more than half a century, CONTAG has been the most constant carrier of that banner, and those who diminish its role ignore the diverse and important contributions the rural labor movement has made to contemporary Brazilian history.

\section{Acknowledgements}

The authors thank issue organizers Rebecca Tarlau and Anthony Pahnke, as well as Editor Jun Borras for soliciting this contribution and having enough patience to let us 'finish' it. We are also grateful to Rebecca for translating several parts of the manuscript. Two anonymous reviewers offered many helpful comments and questions to improve the piece. We are also grateful for diverse grants from Brazilian funding agencies such as Brazil's National Science and Technology Research Council $(\mathrm{CNPq})$ and CAPES, that have been important sources for the scholarship, research materials, travel financing and time needed to complete the paper.

\section{References}

Almeida, A.W.B. 1991. Aggiornamento agônico. Rio de Janeiro. Unpub. Mss.

Alves, F.J.C. 1991. Modernização da agricultura e sindicalismo: lutas dos trabalhadores assalariados rurais da região canavieira de Ribeirão Preto. Thesis (Ph.D). Universidade de Campinas.

Alves, M.H.M. 1984. Estado e oposição no Brasil (1964-1984). Petrópolis: Editora Vozes.

Aly Junior, O. 2013. Interview by C. Welch. Tarija, Bolivia.

Balduíno, T. 2004. Interview by C. Welch. Ribeirão Preto, SP.

Bastos, E.R. 1987 [1985]. Sindicalismo no campo no Brasil: direitos trabalhistas e conflitos de terra. In Processo e relações do trabalho no Brasil, 2nd ed. eds. M.T.L Fleury and R.M. Fischer, 12231. São Paulo: Atlas.

Borras, S.M., M. Edelman, and C. Kay, eds. 2008. Transnational Agrarian Movements: Confronting Globalization. Oxford: Blackwell Publishing. 
Brazil. 1988. Constituição da República Federativa do Brasil de 1988. http://www.planalto.gov.br/ ccivil_03/constituicao/constituicao.htm (accessed August 2, 2014).

Brazil. 2001. Medida Provisória n 2.183-56, de 24 de agosto. Brasília, Presidência da República. http://www.planalto.gov.br/ccivil_03/mpv/2183-56.htm (accessed December 20, 2014).

Brazil. 2006. Lei $\mathrm{n}^{\circ}$ 11.326, de 24 de julho. Brasília, Presidência da República. http://www.planalto. gov.br/ccivil_03/_ato2004-2006/2006/lei/111326.htm (accessed September 14, 2014).

Brazil, Government of. 1946. Constituição dos Estados Unidos do Brasil (de 18 de setembro de 1946). http://www.planalto.gov.br/ccivil_03/constituicao/constituicao46.htm (accessed August 2, 2014).

Bruno, R. 1995. O Estatuto da Terra: entre a conciliação e o confronto. Estudos sociedade e agricultura 5(Nov): 5-31.

Camargo, A.deA. 1986. A questão agrária (1930-1964). In História geral de civilização brasileira. $O$ Brasil republicano: sociedade e política, ed. B. Fausto, 121-224. São Paulo: Difel.

Canuto, A. 2006. Interviewed by C. Welch. Goiânia, GO.

Carneiro, M.J. 1997. Política pública e agricultura familiar: uma leitura do Pronaf. Revista Estudos Sociedade e Agricultura 8: 70-82.

Carvalho, J.M. 2004. Cidadania no Brasil: o longo caminho. Rio de Janeiro: Editora Civilização Brasileira.

Coletti, C. 2002. Ascensão e refluxo do MST da luta pela terra na década neoliberal. Ideias 9, no. 1: 49-104.

Costa, L.F.C. 1993. O Congresso Nacional Camponês: trabalhador rural no processo politico brasileiro. Rio de Janeiro: Universidade Rural.

CONTAG. 1985. Anais do IV Congresso Nacional dos Trabalhadores Rurais: sincialismo forte e reforma agrária já. Brasília: DF.

CONTAG. 1991. Anais do $5^{\circ}$. Congresso Nacional de Trabalhadores Rurais. Brasília: DF.

CONTAG. 1995. Anais do $6^{\circ}$. Congresso Nacional de Trabalhadores Rurais: nem fome, nem miséria; o campo é uma solução. Brasília: DF.

CONTAG. 1997. Desenvolvimento local sustentável baseado na agricultura familiar: construindo um projeto alternativo. Brasília: DF.

CONTAG. 1998. Anais do VII Congresso Nacional de Trabalhadores e Trabalhadoras Rurais: rumo a um projeto alternativo de desenvolvimento rural sustentável. Brasília: DF.

CONTAG. 2001. Documento-base do $8^{\circ}$ Congresso Nacional de Trabalhadores Rurais. Brasília: DF.

CPT - Comissão Pastoral da Terra. 1983. CPT: pastoral e compromisso. Goiânia/Petrópolis: CPT/Ed. Vozes.

Cunha, P.R.da. 2007. Aconteceu longe demais: a luta pela terra dos posseiros em Formoso e Trombas e a revolução brasileira (1950-1964). São Paulo: Edunesp.

Davatz, T. 1980 [1850]. Memórias de um colono no Brasil (1850). São Paulo/Belo Horizonte: Editora da Universidade de São Paulo: 105-73.

Deere, C. D., and L. S. Medeiros. 2008. Agrarian reform and poverty reduction: lessons from Brazil. In Land, poverty and livelihoods in an era of globalization: perspectives from developing and transition countries, eds. A.H Akram-Lodhi, S.M. Borras Jr., and C. Kay, 80-118. London/ New York: Routledge.

D’Incao, M.C. 1975. O 'bóia-fria': acumulação e miséria. Petrópolis: Editora Vozes.

Domingues, J.M. 2002. A dialética da modernização conservadora e a nova história do Brasil. Dados 45: 459-82.

Duarte, E.G. 1998. Do mutirão à ocupação de terras: manifestações camponesas contemporâneas em Goiás. Thesis (PhD.), Universidade de São Paulo.

ESP. 1973. Industriários de cana fazem dia 19 a primeira reunião. O Estado de S. Paulo 18 May: 16.

FAO/INCRA. 1994. Diretrizes de política agrária e desenvolvimento sustentável para a pequena produção familiar. Brasília, DF: FAO/INCRA.

Fernandes, B.M. 1996. MST: formação e territorialização. São Paulo: Editora Hucitec.

Fernandes, B.M. 2002. Agricultura camponesa e/ou agricultura familiar. http://www.geografia.fflch.usp. br/graduacao/apoio/Apoio/Apoio_Valeria/flg0563/2s2012/FERNANDES.pdf (accessed June 6, 2013).

Fernandes, B.M., C.A. Welch, and E.C. Gonçalves. 2012. Land governance in Brazil: a geo-historical review of land governance in Brazil. Roma: International Land Coalition. http://www. landcoalition.org/publications/land-governance-brazil (accessed November 1, 2012).

Ferreira, J. 2011. João Goulart. uma biografia. Rio de Janeiro: Civilização Brasileira. 
FNRA - Forum Nacional pela Reforma Agrária e Justiça no Campo. 2005. Análise conjuntural reforma agrária. Brasília: D.F. http://terradedireitos.org.br/en/2005/12/19/analise-conjunturalreforma-agraria/ (accessed July 29, 2014).

FNRA - Forum Nacional pela Reforma Agrária e Justiça no Campo. 2008. Nota do Fórum Nacional pela Reforma Agrária e Justiça no Campo sobre um novo marco legal e institucional para a Amazônia. Brasília: D.F. http://www.cnbb.org.br/comissoes-episcopais-1/caridade-justica-epaz/495-nota-do-forum-nacional-pela-reforma-agraria-e-justica-no-campo-sobre-um-novo-marcolegal-e-institucional-para-a-amazonia (accessed July 29, 2014).

Ganzer, A. 1997. Interviewed by C. Welch. Taguatinga: DF.

Gonçalves Neto, W. 1997. Estado e agricultura no Brasil: política agrícola e modernização econômica brasileira, 1960-1980. São Paulo: Editora Hucitec.

Grito da Terra Brasil. 1995. Pauta nacional de reivindicações. Brasilia: DF. 24 May.

Grzybowski, C. 1991. Caminhos e descaminhos dos movimentos sociais no campo. Petrópolis/Rio de Janeiro: Vozes/Fase.

Hall, M.M. and P.S. Pinheiro. 1985. Alargando a história da classe operária: organização, lutas e controle. Remate de Males 5: 95-119.

Horiguti, Roberto Toshio. 1979. O Estatuto da Terra e a posição do trabalhador rural. Boletim da Associação Brasileira de Reforma Agrária 9, no. 6: 21-28.

Houtzager, P.P. 2004. Os últimos cidadãos: conflito e modernização no Brasil rural. São Paulo: Editora Globo.

Iokoi, Z.M.G. 1996. Igreja e camponeses: teologia da libertação e movimentos sociais no campo Brasil e Peru. São Paulo: Editora Hucitec.

Julião, F. 2009 [1962]. Que são as Ligas Camponesas?. In Camponeses brasileiros: leituras e interpretações clássicas, eds. C.A. Welch, E. Malagodi, J.S.B. Cavalcanti, and M.N.B. Wanderley, 271-97. São Paulo: Editora da Unesp.

Karepovs, Dainis. 2006. A classe operária vai ao parlamento. o bloco operário e camponês do Brasil (1924-1930). São Paulo: Alameda Casa Editorial.

Lamarche, H., ed. 1993. A agricultura familiar, comparação internacional. Campinas: Editora da Unicamp.

Linhares, M.Y. and F.C.T. Silva. 1999. Terra prometida: uma história da questão agrária no Brasil. Rio de Janeiro: Editora Campus.

Martine, G. 1987. Êxodo rural, concentração urbana e fronteira agrícola. In Os impactos sociais da modernização agrícola, eds. G. Martine and R.C. Garcia, 59-79. São Paulo: Editora Caetes.

Martins, J.S. 1981. Os camponeses e a política no Brasil. Petrópolis: Editora Vozes.

Martins, J.S. 1988. Não há terra para plantar neste verão: o cerco das terras indígenas e das terras de trabalho no renascimento político do campo. Petrópolis: Ed. Vozes.

Martins, J.S. 2002. Representing the peasantry?. Struggles for/about Land in Brazil. Journal of Peasant Studies 29, no. 3-4: 300-35.

Maybury-Lewis, B. 1994. The politics of the possible: The Brazilian rural workers' trade union movement, 1964-1985. Philadelphia: Temple University Press.

Medeiros, L.S. de. 1989. História dos movimentos sociais no campo. Rio de Janeiro: FASE.

Medeiros, L.S. de. 1993. Reforma agrária: concepções, controvérsias e questões. Rio de Janeiro, Unpub. mss. http://www.cefetsp.br/edu/eso/reformaagrariaquestoes.html (accessed December 20, 2014).

Medeiros, L.S. de. 2012. Sindicalismo rural. In Dicionário de educação do campo, eds. R. Caldart et al., 706-13. São Paulo: Expressão Popular/Fiocruz.

Minc, C. 1985. A reconquista da terra: Estatuto da Terra, lutas no campo e reforma agrária. Rio de Janeiro: Zahar.

Montenegro, A. T. 2004. As Ligas Camponesas às vesperas do golpe de 1964. Projeto História, v.29, Tomo 2, p. 391-416.

Moore, B. 1966. Social origins of democracy and dictatorship: lord and peasant in the making of the modern world. Boston: Beacon Press.

NERA - Núcleo de Estudos, Pesquisas e Projetos de Reforma Agrária. 2013. DATALUTA Banco de Dados da Luta pela Terra: Relatório 2012, eds. E.P. Girardi and B.M. Fernandes, Presidente Prudente, São Paulo: UNESP.

Oliveira, A.U. 2010. A questão da aquisição de terras por estrangeiros no Brasil - um retorno aos dossiês. Revista Agrária 12: 3-113. http://www.revistas.usp.br/agra/article/view/702/711 (accessed September 17, 2012). 
Palacios, G. 2009 [1987]. Campesinato e escravidão: uma proposta de periodização para a história dos cultivadores pobres livres no Nordeste oriental do Brasil (1700-1875). In Camponeses brasileiros, eds. Welch et al., 145-78.

Palmeira, M. 1985. A diversidade da luta no campo: luta camponesa e diferenciação do campesinato. In A Igreja e questão agrária, ed. V. Paiva, 43-51. São Paulo: Edições Loyola.

Palmeira, M., and S. Leite. 1998. Debates econômicos, processos sociais e lutas políticas. In Política e reforma agrária, eds. L.F.C Costa and R. Santos, 92-169. Rio de Janeiro: Editora Mauad.

Paulino, E. T. 2014. The agricultural, environmental and socio-political repercussions of Brazil's land governance system. Land Use Policy 36: 134-44.

Pereira, A.W. 2005. Political injustice: authoritarianism and the rule of law in Brazil, Chile and Argentina. Pittsburgh: Pittsburgh University Press.

Pereira, J.M., and S. Sauer. 2011. A 'reforma agrária assistida pelo mercado' do Banco Mundial no Brasil: dimensões políticas. implantação e resultados. Sociedade e Estado 26, no. 3: 587-612.

Pinheiro Neto, J. 1993. Jango: um depoimento pessoal. Rio de Janeiro: Editora Record.

Poletto, I. 1985. A CPT, a Igreja e os camponeses. In Conquistar a terra, reconstruir a vida, eds. D.P. Casaldáliga, et al., 29-66. Petrópolis: Vozes.

Poletto, I. 1990. A pastoral da terra e a construção da democracia. Cadernos de Estudos da CPT no. 1: $1-24$.

Price, R.E. 1964. Rural unionization in Brazil. Land Tenure Center Report, 14, Madison: University of Wisconsin.

Priori, A. 2011. O levante dos posseiros: a revolta camponesa de Porecatu e a ação do Partido Comunista Brasileiro no campo. Maringá, PR: Editora da Universidade Estadual de Maringá.

Ribeiro, A.S. 2013. Entrevista pelo Memórias DNTR-CUT. http://memoriasdntrcut.wordpress.com/2013/ 09/03/trampolim-foi-uma-semente-que-a-gente-plantou/\#more-132 (accessed on November 14, 2013).

Ricci, R. 1999. Terra de ninguém: representação sindical rural no Brasil. Campinas: Editora da Unicamp.

Sauer, S. 1996. The land issue as a theological problem: the Roman Catholic and Lutheran Churches' social and political commitment to the struggle for land in Brazil. Thesis (MA), Stavanger School of Mission and Theology.

Sauer, S. 2002. Terra e modernidade: a dimensão do espaço na aventura da luta pela terra. Thesis $(\mathrm{PhD})$, Universidade de Brasília.

Sauer, S. 2010. Terra e modernidade: a reinvenção do campo brasileiro. São Paulo: Expressão Popular.

Sauer, S. 2012. Articulações em defesa da reforma agrária. In Dicionário de educação do campo, eds. R. Caldart, et al., 103. São Paulo: Expressão Popular/ Fiocruz.

Sauer, S. 2013. O Governo Lula no campo: compromissos e embates nas políticas agrárias e agrícolas. In Trajetória e dilemas da reforma agrária no Brasil, ed. L. Mattei, Florianópolis. (forthcoming).

Schneider, S., L. Mattei, and A.A. Cazella. 2004. Histórico, caracterização e dinâmica recente do PRONAF. In Políticas públicas e participação social no Brasil rural, eds. S. Scheider, M.K. Silva, and P.E.M. Marques, 21-50. Porto Alegre: Editora da UFRGS.

Siguad, L. 1980. Greve nos engenhos. Rio de Janeiro: Editora Paz e Terra.

Silva, J.G. da. 1971. A reforma agrária no Brasil: frustração camponesa ou instrumento de desenvolvimento?. Rio de Janeiro: Zahar Editores.

Silva, J.G. da. 1982. A modernização dolorosa: estrutura agrária, fronteira agrícola e trabalhadores rurais no Brasil. Rio de Janeiro: Zahar Editores.

Silva, J.G. da. 1987. Caindo por terra: crises da reforma agrária na Nova República. São Paulo: Busca Vida.

Silva, J. Gomes da. 1989. Buraco negro: a reforma agrária na constituente de 1987/88. São Paulo: Editora Paz e Terra.

Silva, M.A.M. 1998. Errantes do fim do século. São Paulo: Editora da Unesp.

Simon, C.G.B. 1998. Os campos dos senhores: UDR e elite rural - 1985/1988. Londrina: Editora UEL.

Stedile, J.P., ed. 2005. A questão agrária no Brasil: programas de reforma agrária: 1946-2003. São Paulo: Expressão Popular.

Thomaz, Jr., A. 2002. Por trás dos canaviais, os 'nós' da cana: a relação capital x trabalho e o movimento sindical dos trabalhadores na agroindústria canavieira paulista. São Paulo: Annablume Editora e Comunicação. 
Vangelista, C. 1991. Os braços da lavoura: imigrantes e 'caipiras' na formação do mercado de trabalho paulista (1850-1930). São Paulo: Editora Hucitec.

Wanderley, M.N.B. 2003. Agricultura familiar e campesinato: rupturas e continuidade. Estudos Sociedade e Agricultura 21 (Oct): 42-61.

Welch, C.A. 1995. Rivalry and unification: mobilising rural workers in São Paulo on the eve of the Brazilian golpe of 1964. Journal of Latin American Studies 30, no. 2: 61-89.

Welch, C.A. 1999. The seed was planted: the São Paulo roots of Brazil's rural trade union movement. State College, PA: Penn State Press.

Welch, C.A. 2005. Agribusiness: Uma breve história do modelo norteamericano. In Anais do X Encontro de Geógrafos da América Latina, 16467-505. São Paulo: Universidade de São Paulo.

Welch, C.A. 2006a. Movimentos sociais no campo: a literatura sobre as lutas e resistências dos trabalhadores rurais do século XX. Revista Lutas e Resistências (Londrina, PR), 1, 60-75.

Welch, C.A. 2006b. Keeping communism down on the farm: the Brazilian rural labor movement during the cold war. Latin American Perspectives 33, no. 3: 28-50.

Welch, C.A. 2009a. Camponeses: Brazil's peasant movement in historical perspective (1946-2004). Latin American Perspectives 36, no. 4: 126-55.

Welch, C.A. 2009b. Os camponeses entram em cena: a iniciação da participação política do campesinato paulista. In Formas de resistência camponesa: visibilidade e diversidade de conflitos ao longo da história. v. 2: Concepções de justiça e resistência nas repúblicas do passado (19301960). Coleção História Social do Campesinato no Brasil, eds. M. Motta and P. Zarth, 29-51. São Paulo: Editora da UNESP.

Welch, C.A. 2010. A semente foi plantada: as raizes paulistas do movimento sindical camponês no Brasil (1924-1984). São Paulo: Expressão Popular.

Welch, C.A. 2011. Lula and the meaning of agrarian reform. NACLA: Report on the Americas 44, no. 2: $27-30$.

Clifford Andrew Welch is professor of contemporary Brazilian history at São Paulo Federal University (UNIFESP). He also teaches in the postgraduate program on Latin American and Caribbean Territorial Development at São Paulo State University (UNESP), where he is a researcher in the Center for Agrarian Reform Research, Study and Projects (NERA). In 2014, he completed a senior leave postdoctorate as Humanities Research Associate in History at the University of California - Santa Cruz, made possible by a grant from Brazil's Coordinator for Improvement Higher Education Personnel (CAPES). Email: cliff.a.welch@gmail.com

Sérgio Sauer is a professor of agrarian themes at the University of Brasília (Planaltina Campus of the $\mathrm{UnB}$ ) and in the Post-Graduate Program on Environment and Rural Development, Mader. He is a visiting professor at the International Institute of Social Studies (ISS) in The Hague and his postdoctoral research is on land grabbing, with a grant from CAPES. Email: sauer.sergio@gmail.com 